\title{
STUDY OF EXTERNAL EYE DIMENSIONS AS POSSIBLE TOOL FOR SEX IDENTIFICATION IN EGYPTIAN POPULATION
}

\author{
Sarah A. Khater $^{\mathrm{a}}$,Sahar Ibrahim ${ }^{\mathrm{b}}$,MostfaAbdAllah ${ }^{\mathrm{c}}$ and Ezz El Din Shalaby ${ }^{\mathrm{d}}$ \\ ${ }^{a}$ Lecturer of Forensic Medicine and Clinical Toxicology Department, Misr University \\ for Science \& technology. \\ ${ }^{\mathrm{b}}$ Lecturer of Ophthalmology Department, Beni-Suef University. \\ ${ }^{c}$ Lecturerof Forensic Medicine and Clinical Toxicology Department, Beni-Suef \\ University. \\ ${ }^{\mathrm{d}}$ Lecturer of Forensic Medicine and Clinical Toxicology Department, Cairo \\ University.
}

Corresponding author: Ezz El Din Shalaby:ezz.shalaby @yahoo.com.

\begin{abstract}
Recognition of sex through eye dimensions is important especially that these dimensions is fixed after puberty and not liable for reshape especially in cases of intersex, mutilation of the genitalia ,transsexual cases and mass disasters use of eye recognition as a biometric identification tool is accurate. Aim of the study: The aim of our study is to evaluate the difference in external eye dimensions: 1- Inter palpebral distance, 2-Intercanthus distance and 3- Eye width (width of palpebral fissure) between males and females in order to establish a primary a database to help in sex identification in Egyptian population.. Methods: in our study 100 subjects (49males and 51 females) ranging from 15 to 30 years old were randomly chosen from ophthalmology outpatient clinic, Beni-Suef University, Egypt. Inter palpebral distance,Intercanthus distance and eye width were taken. The result throughout the studywas revealed the gender plays a substantial role across the width of palpebral fissure parameter; data collected can be used as preliminary database for further research in the field of forensic medicine for sex identification.
\end{abstract}

KEYWORDS: Eye shape, External eye dimensions, Sex, Egypt.

\section{INTRODUCTION}

Human beings can distinguish between a male and a female face without much difficulty (Pascalis et al., 2002). The orbit is an essential anatomical landmark of skull and orbital measurements are one of the craniofacial parameters that could be used in sex identification in terms of anthropological studies (Jain et al., 2015).

As digital image evidence becomes more readily available, facial recognition begins to play a key role in solidifying testimonies and leading to conviction of criminals. Every year the endeavored arrangements ascend in trouble and affecting occasions. Although the field of facial recognition has become widely studied in the most recent years, there is significant capacity for improvement in the efficacy of this work (Hiremath et al., 2007).

The ability to utilize eye recognition as a biometric identification tool is provento bemore accurate and more reliable than the use of other 
biometrics such as fingerprints. Where fingerprints are exposed to environment and can be morphed, the eyes are guarded by a protective cover and remain predominately unchanged for decades. As a vital feature of the human face, the eye plays a crucial role in facial recognition and facial expression analysis(Desaiet al., 2013).

There are numerous contours of eyes; like intercanthusdistance that is may have importance in sex identification(Bochan,2006). Sex determination is considered important for identification for use as in facial reconstruction, there were studies performed on sexual dimorphism from different skeletal parts, which used differentosteometric and morphological approaches (Loth and Iscan, 2000).

In Malaysia, the utilization of an application named Photofit was made known when it was connected on account of hijack, rape and murder of NurinJazlin in 2007. It was used, again, in the UK in the case of the kidnapping of, banker, Peter Shaw's case in 2002(Gabriel et al., 2017).

Our research looked into sex identification through eye dimensionsfrom Egyptian population with no exclusion criteriatheir age ranging between 15 and 30 years old.

\section{AIM OF STUDY}

The aim of our study is to evaluate the difference in external eye dimensions: 1- Inter palpebral distance, 2-Intercanthus distance and 3- Eye width (width of palpebral fissure) between males and females in Egypt in order to establish a primary a database to help in sex identification.

\section{MATERIAL AND METHODS}

A total of 100 subjects, 49Male and 51 female areincluded in the study. After approval of ethical committee and written consent of participants, Sample size was determined guided by PASS 2008 platform as a service sample size calculator (Hurwitz et al .,2012). Subjects were randomlyselected from ophthalmology clinic- faculty of medicine- Beni-Suef University ranging from 15-30 years old. Subjects are of good health with the absence of any hereditary anomalous or history of eye trauma influencing the eyeand not experience any eye plastic surgery who influence the appearance of the natural eye shape.We inform subjects to remove any eye frill, for example, eyeglasses and contact lenses. Also to remove any eye make-up to confirm accuracy of our study.

Subjects had to fulfill matching criteria that would deem the characteristic trait suitable for biometric measurements. Then each individual signed a consent and release form. Consequently, subjects were to remove any eye accessory that could potentially obstruct the gathered evidence. Each tested subject was then asked to sit upright on a chair. A scale measurement ruler was held by the subject's dominant hand beside his/her own eyes to be used as a calibrator. Subjects were then asked to be relax, ensuring no facial expression also (Gabriel et al .,2017).

The objective was to study the external dimension of the eyes for the males and females as possible tool for 
sex identification in Egypt in the following criteria:

1-Inter palpebral distance: which is the distance between the midpoint of upper eyelids.

2-Intercanthus distance: which is the distance between the medial canthi of the palpebral fissures bilaterally.

3- Eye width (width of palpebral fissure): which is the distance between

the elliptic space between the medial and lateral canthi of the two open lids.

Inter palpebral distance between the eyes, the intercanthus distance, and the eye width of both eyes(width of palpebral fissure),were measured using a scale measurement ruler as an assessment. The measurementsare in inches to two decimal places.

Each measurement was repeated twice and an average of all the readings was recorded. In order to prevent and inter-value error or bias, a single observer was responsible for collecting all measurements. Similar instruments and protocols were applied to amplify accuracy of readings, improving quality of the input sample. The measurements were illustrated in figure (1).

All measurements reading arerecorded in the form of numerical data and displayed in a table. The variety of eye shapesresults were categorized by percentage and applied in the form of a graph, then are computed as numerical data and transported into SPSS 12(Armitage et al., 2008)for statistical data analysis. Normal distribution of the data was reviewed before parametric tests were done. Chi square test of independence $(\mathrm{p}<0.05)$ alsoIndependent $\mathrm{t}$-test applied for inter eye distance measurements among sexes.

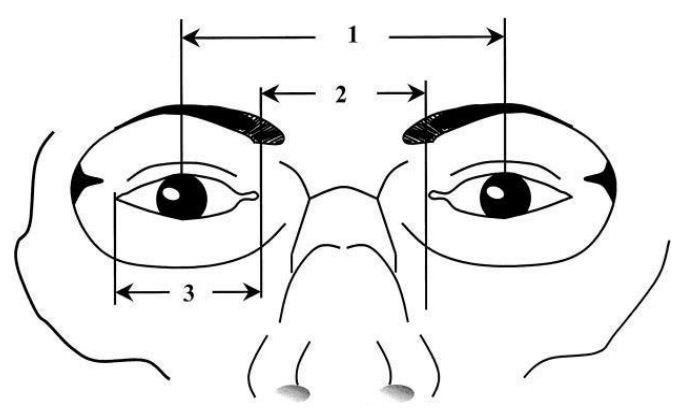

Figure 1: Inter palpebral distance (1), Intercanthus distance (2) and Eye width (width of palpebral fissure) (3).

\section{RESULTS}

A total of 100 subjects (49males and 51 females) their age ranging from 15 to 30 years old were randomly chosen from the population of faculty of medicine, Beni-Suef University, with no racial or geographical exclusion criteria in the study all participants were exposed after written consent to accurate ocular measurementinclude : 1-Inter palpebral distance, 2Intercanthus distance and 3- Eye width(width of palpebral fissure) of each subject were measured .

The mean of the width of palpebral fissure was 31.37 with standard deviation 2.8 , the mean of the interpalpebraldistance was 62.58 with standard deviation 2.76 and the mean of the intercanthus distance was 32.57 with standard deviation 2.48. Base-line characteristics of all participants was taken as shown in table (1),Across sex, this study showed that there was a profound difference between males and females regarding the mean width 
of palpebral fissure $(\mathrm{P}$-value $=0.017)$ as shown in table (2). There was no statistical significant linear correlation between age and the other estimated measures as width of palpebral fissure, interpalpebral distance and intercanthus distance as shown in table (3).There was a statistical significant linear positive moderate correlation between width of palpebral fissure and interpalpebral distance and intercanthus distance as shown in table (3). Inverting the odds ratio for width of palpebral fissure increase in fissure width will increase the probability of being female as shown in table (4).So our study featured the types of inter eye distance across sexes and age range (15 to $30 \mathrm{y}$ old). It is recognizable that no difference in inter palpebral distance and intercanthus distance between male and female, although there is differences in the measurement of inter eye distance within the same type. Because of presence a statistical significant difference between males and females regarding the mean width of palpebral fissure, binary logistic regression was run to predict sex from width of fissurethat female is the reference category.

Table (1): base-line characteristics of all participants

\begin{tabular}{|l|l|l|l|l|}
\hline & Age & $\begin{array}{l}\text { Width of } \\
\text { fissure }\end{array}$ & $\begin{array}{l}\text { Interpalpe } \\
\text { braldistanc } \\
\text { e }\end{array}$ & $\begin{array}{l}\text { Inter canthus } \\
\text { distance }\end{array}$ \\
\hline Mean & 22.8900 & 31.3700 & 62.5800 & 32.5650 \\
\hline Std. Deviation & 4.34357 & 2.80207 & 2.76040 & 2.47886 \\
\hline Minimum & 15.00 & 25.00 & 57.00 & 28.00 \\
\hline Maximum & 30.00 & 35.00 & 70.00 & 40.00 \\
\hline Median & 22.0000 & 30.5000 & 62.0000 & 32.0000 \\
\hline
\end{tabular}


Table (2) comparison between males and females regarding their measured parameters

\begin{tabular}{|c|c|c|c|c|c|c|c|c|c|c|}
\hline & & $\mathrm{N}$ & Mean & $\begin{array}{c}\text { Std } \\
\cdot \\
\text { De } \\
\text { viat }\end{array}$ & $\begin{array}{c}\mathrm{P}- \\
\text { value }\end{array}$ & $\mathrm{T}$ & \multicolumn{2}{|c|}{$\begin{array}{c}95 \% \\
\text { Confidence } \\
\text { Interval for } \\
\text { Mean }\end{array}$} & \multirow[t]{2}{*}{$\begin{array}{l}\text { Mini } \\
\text { mum }\end{array}$} & \multirow[t]{2}{*}{$\begin{array}{l}\text { Maxi } \\
\text { mum }\end{array}$} \\
\hline & & & & & & & $\begin{array}{l}\text { Lowe } \\
\text { r } \\
\text { Boun } \\
\text { d }\end{array}$ & $\begin{array}{l}\text { Upp } \\
\text { er } \\
\text { Bou } \\
\text { nd }\end{array}$ & & \\
\hline \multirow{2}{*}{$\begin{array}{l}\text { Width of } \\
\text { fissure }\end{array}$} & Males & 49 & 30.69 & 2.7 & \multirow[t]{2}{*}{$0.017 *$} & \multirow[t]{2}{*}{2.42} & 29.8 & 31.4 & 25.00 & 35.00 \\
\hline & Females & 51 & 32.01 & 2.6 & & & 31.2 & 32.7 & 28.00 & 35.00 \\
\hline \multirow{2}{*}{$\begin{array}{r}\text { Interpalp } \\
\text { ebraldista } \\
\text { nce }\end{array}$} & Males & 49 & 62.34 & 2.6 & \multirow[t]{2}{*}{0.411} & \multirow{2}{*}{$\begin{array}{c}0.82 \\
6\end{array}$} & 61.5 & 63.1 & 57.00 & 68.00 \\
\hline & Females & 51 & 62.8 & 2.8 & & & 62 & 63.5 & 58.00 & 70.00 \\
\hline \multirow{2}{*}{$\begin{array}{r}\text { Inter } \\
\text { canthusdi } \\
\text { stance }\end{array}$} & Males & 49 & 32.43 & 2.4 & \multirow[t]{2}{*}{0.620} & \multirow{2}{*}{$\begin{array}{c}0.49 \\
7\end{array}$} & 31.7 & 33.1 & 28.00 & 39.00 \\
\hline & Females & 51 & 32.68 & 2.4 & & & 31.9 & 33.3 & 29.00 & 40.00 \\
\hline \multicolumn{11}{|c|}{$\begin{array}{l}\text { There was a statistical significant difference between males and females regarding the mean width of fissure (P- } \\
\text { value }=0.017)\end{array}$} \\
\hline
\end{tabular}

Table(3) Correlation between age, width of palpebral fissure, inter palpebral distance and inter canthus distance

\begin{tabular}{|l|l|l|l|l|l|}
\hline \multicolumn{2}{|l|}{} & Age & $\begin{array}{l}\text { Width of } \\
\text { fissure }\end{array}$ & $\begin{array}{l}\text { Interpalpebral } \\
\text { distance }\end{array}$ & $\begin{array}{l}\text { Inter canthus } \\
\text { distance }\end{array}$ \\
\hline \multirow{2}{*}{ Age } & $\mathrm{R}$ & 1 & -.110 & .008 & .043 \\
\cline { 2 - 6 } & P-value & & .275 & .938 & .672 \\
\hline \multirow{2}{*}{ Width of fissure } & $\mathrm{R}$ & -.110 & 1 & $\mathbf{. 4 6 2}^{* *}$ & $\mathbf{. 5 7}^{* *}$ \\
\cline { 2 - 6 } & P-value & .275 & & $\mathbf{. 0 0 0}$ & $\mathbf{. 0 0 0}$ \\
\hline \multirow{2}{*}{$\begin{array}{l}\text { Interpalpebral } \\
\text { distance }\end{array}$} & $\mathrm{R}$ & .008 & & 1 & $\mathbf{. 3 5 7 ^ { * * }}$ \\
\cline { 2 - 6 } & P-value & .938 & & & $\mathbf{. 0 0 0}$ \\
\hline \multirow{2}{*}{$* *$ Correlation is significant at the 0.01 level (2-tailed). } & & \\
\hline
\end{tabular}


There was no statistical significant linear correlation between age and the other estimated measures as width of fissure, interpalpebral distance and inter canthus distance.

There was a statistical significant linear positive moderate correlation between width of fissure and interpalpebraldistance and inter canthus distance. Because of presence a statistical significant difference between males and females regarding the mean width of fissure, binary logistic regression was run to predict sex from width of fissure.

Table (4) binary logistic regression model for prediction of sex from Width of palpebral fissure

\begin{tabular}{|l|l|l|l|l|l|l|}
\hline $\begin{array}{l}\text { Independent } \\
\text { variable }\end{array}$ & $\mathbf{B}$ & $\begin{array}{l}\text { Wald } \\
\text { test }\end{array}$ & $\begin{array}{l}\text { P- } \\
\text { value }\end{array}$ & \multirow{2}{*}{ OR } & \multicolumn{2}{|c|}{ 95\% C.I for OR } \\
\cline { 4 - 7 } \\
$\begin{array}{l}\text { Width of } \\
\text { fissure }\end{array}$ & -0.178 & 5.4 & $\mathbf{0 . 0 2 0}$ & 0.837 & 0.720 & 0.972 \\
\hline Constant & 5.5 & 5.3 & 0.021 & 254.9 & & \\
\hline
\end{tabular}

Female is the referencecategory:Btest:the probability of two events happening at the same time.P value:is the probability to the right of respective statistic. Wald test: is one of independent variable used as a way to find out if explanatory variables in a model are significant.OR test: is a probability factor observed frequency count.

Inverting the odds ratio for width of fissure increase in fissure width will increase the probability of being female.

\section{DISCUSSION}

Sex determination is very important for identification in forensic medicine ,medico legal cases and forensic anthropologists. Sex determination is reliable in cases where an intact body is available. The same is difficult when only part of the body is found. It is often difficult for forensic anthropologists when only facial photographs or head or facial remains are brought for examinations because the standards available and the accessibility in this direction are very less. Hence facial measurements are useful in the absence of other evidence for sex estimation (Twisha et al., 2016).

In our study we assess 3 external eye shape dimensions for sex identification in Egyptian population inter palpebral distance, inter canthus distance and eye width (width of palpebral fissure) in our study result show that inter palpebral distance, inter canthus distance is not important for sex identification but eye width (width of palpebral fissure) is very important for sex identification in Egyptian population. Our study is going with Twisha et al ,.(2016) which was done in India which show the mean values of all the eight cephalo-facial measurements including $\mathrm{Bi}$ ocular 
breadth were greater in males than females. Two techniques, logistic regression and discriminant function analysis, were performed to check for the best reliable results including $\mathrm{Bi}$ ocular breadth.

Our study is againstAdamu et al., (2016)study which was done in Hausa population of Kano StateNigeria result which showAll the facial linear dimensions showed significant sexual dimorphism except interocular distance, upper facial width, philtrum length, lower vermilion width, left and right orbital width for facial angles, only nasion and aperture modified angle did not show significant sex differences.

As regard sex this study showed that there was a statistically significant difference between males and females regarding the mean width of palpebral fissure (P-value=0.017). While in another study there was no significant conclusion for types of inter eye distance amongboth sexes (Kumah et al., 2016).

There are around 3 billion nucleotides in a human body and each individual differs by an average of 2 to 3 million base pairs. Such huge contrasts in the hereditary pool definitely cause some type of varieties among people (Glaser et al., 1992). $88 \%-90 \%$ of hereditary varieties between every person and 10\%-12\% of varieties among various populationsdistinguished. This explain that the differences in inter eye distance measurement among genders were valid and justified (Murray et al., 2017).

Our study is going with Senthil, (2019) study which was done in India show that interpupillary distance were higher in males than in females and thus sexual dimorphism exists. Fissure height and biocular width were more in Indian males when compared to Indian females. Also our study is going with Vasanthakumaret al.,(2013) study which show that palpebral fissure width: In male had longer palpebral fissure than the female subjects and they showed statistically significant sexual differences (males: $31.08 \mathrm{~mm}$; females: $29.9 \mathrm{~mm}$ ). By comparison also withSenthil, (2019) study which was done in Malaysia and India also Fissure height and interocular width were more in Malaysian female when compared to other groups. Indian males and females differed significantly in upper and lower eye lids height from Malaysian males and females. All eye morphometric parameters except interpupillary distance were increased in Malaysians when compared to Indians which means that there is racial variability also so our study in Egyptian population is important to evaluate role of eye shape external dimension database.

AlsoGabriel et al., (2017)studywhich was done in ChinaAnalysis indicated that there was significant difference across the types of inter eye distance and inters eye distance measurement between the Chinese and Malays. This finding is in line with that suggested the chromosome 11 to be responsible for determining the final outcome of inter eye distance.So our study is important to determine sex identification in Egyptian nation by determination of external eye dimension as we can not depend on other study in other 
population as there is racial difference proven as by this study.

\section{Conclusion}

Based on the findings after thorough study, the measurements of Eye width (width of palpebral fissure)could potentially be a useful tool in recognition of sex by eye dimension is important especially that these dimensions is fixed after puberty and not liable for reshape especially in cases of intersex, mutilation of the genitalia,transsexual cases and mass disasters, as forensic evidence in sex identification as by our study.

\section{REFERENCES}

Adamu, L.H., Ojo, S.A., Danborno, B., Adebisi, S.S. and Taura, M.G. (2016): Sex determination using facial linear dimensions and angles among Hausa population of Kano State, Nigeria. Egyptian Journal of Forensic Sciences, 6(4), pp.459467.

Armitage, P., Berry, G. and Matthews, J.N.S. (2008): Statistical methods in medical research. John Wiley and Sons book chapter 3 page number 33-35.

Bochan, T.(2006): Modeling and Self Improvement. Step by Step book. Chapter3 eye description, page 1819, Trafford Publishing, UK.

Desai, N., Dharia, V., Shah, I. and Prajapati, G. (2013):Detecting the location of eyes on the front facial images using two-phase method. International Journal of Innovative Research in Computer and Communication Engineering, 1(3), pp.673-679.

Gabriel, G.F., Hamzah, S.P.A.A., Sia, B.P., Osman, K., Anan, A. and
Baba, M.H. (2017):Development of Eye Shape Photofit Database of the Chinese and Malay population in Malaysia. SM J Forensic Res Criminol, 1(3), p.1011.

Glaser, T., Walton, D.S. and Maas, R.L. (1992): Genomic structure, evolutionary conservation and aniridia mutations in the human PAX6 gene. Nature genetics, 2(3), p.232.

Hiremath, P.S., Danti, A., Prabhakar, C.J., Delac, K. and Grgic, M. (2007): Modelling uncertainty in representation of facial features for face recognition. Face Recognition, 10, pp.183-218.

Hurwitz, J., Kaufman, M., Halper, F. and Kirsh, D.(2012): What Is Platform as a Service (PaaS) in Cloud Computing?.Hybrid Cloud For Dummies, Hoboken, NJ: John Wiley and Sons book chapter 2 page number 45-48.

Jain, D., Jasuja, O.P. and Nath, S. (2015):Determination of sex using orbital measurements. Ind. J. Phys. Anthrop. \& Hum. Genet, 34(1), pp.97-108.

Kumah, D.B., Akuffo, K.O., AbakaCann, J.E., Ankamah, E. and Osae, E.A.(2016):Interpupillary Distance Measurements among Students in the Kumasi Metropolis. Optom Open Access, 1(103), p.2.

Loth, S.R., and Iscan, M.Y.(2000): Sex determination. Encyclopedia of Forensic Sciences J. San Di-ego, CA: Academic Press, volume 3, p.252-60.

Murray, N.P., Hunfalvay, M. and Bolte, T. (2017): The reliability, validity, and normative data of interpupillary distance and pupil diameter using eye- 
trackingtechnology. Translational Vision Science \& Technology, 6(4), pp.2-2.

Pascalis, O., Haan, M. and Nelson, C.A. (2002):Is face processing species-specific during the first year of life?.Science, 296(5571), pp.1321-1323.

Senthil, K. (2019):Sex Determination by Morphometry of Eye. Journal of Krishna Institute of Medical Sciences University 8(1):80-85.

Twisha, S. M., Patel S., Nath S. and Menon K. (2016): Determination of sex using cephalo-facial dimensions by discriminant function and logistic regression equations.

Egyptian Journal of Forensic Sciences, Volume 6, Issue 2, Pages 114-119.

Vasanthakumar, P., Pramod ,K. and Mohandas R. (2013): Anthropometric Analysis of Palpebral Fissure Dimensions and its Position in South Indian Ethnic Adults. Oman Med J.28(1): 26-32. 


\section{دراسة ابعاد العين الخارجية كوسيلة لمعرفة الجنس عند المصريين}

سارة خاطر *، سحر إبر اهيم***، مصطفى عبدالل ******، عز الدين شلبي

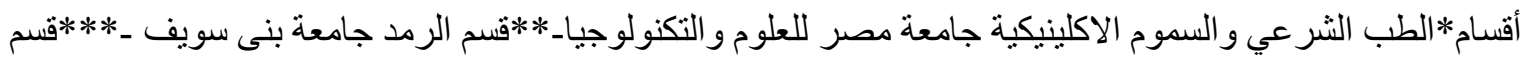

الطب الثر عي و السموم الاكلينيكية جامعة بنى سويف_*****:الطب الثر عي و السموم الاكلينيكية جامعة القاهرة

ان للوجه دور كبير في معرفة الجنس ، وان العينين و ابعادها ممكن ان تستخدم في معرفة الجنس، وان الصورة الرقمية

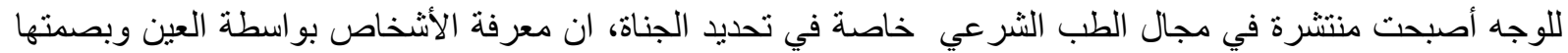

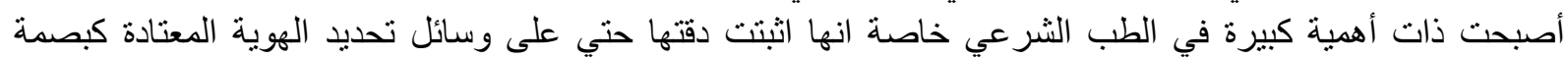

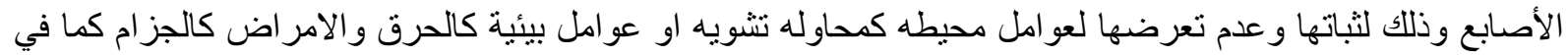

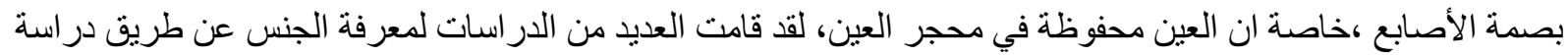

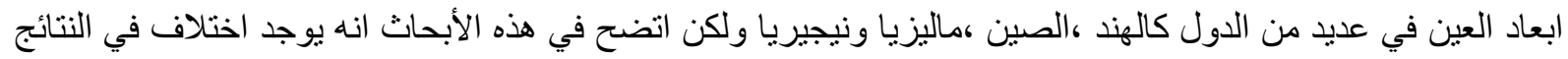

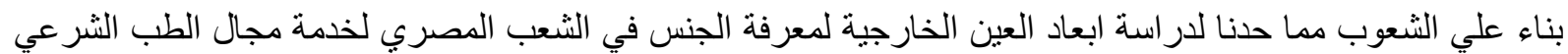
في تحديد الجنس بمصر.

أن معرفة الجنس له أهمية كبيرة في الطب الثرعي- ومعرفة الجنس عن طريق ابعاد العين هام جدا حيث ان ابعاد العين

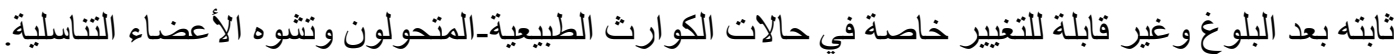

ولذلك كان الهدف در استتا هو در اسة ابعاد العين الخارجية كوسيلة لمعرفة الجنس في المصريين- و التي تم عملها بمستشفى التهى

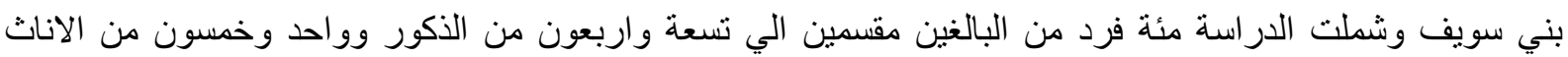

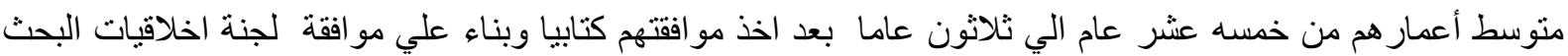

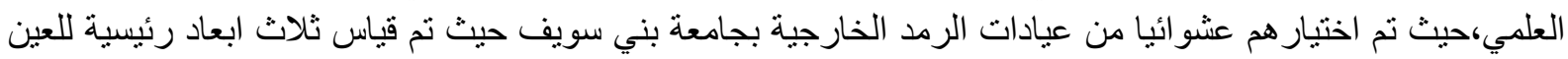

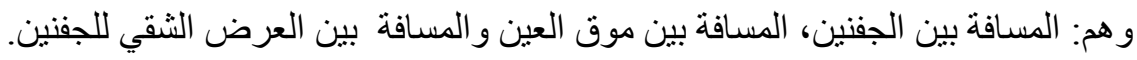

وقد اثتتت دراستنا أن المسافة بين العرض الثقي للجفنين لها دور كبير في معرفة الجنس عند المصريين ، اما المسافة بين

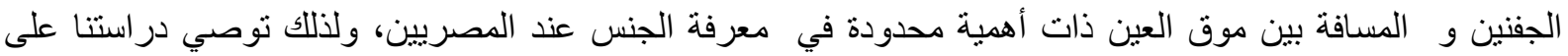

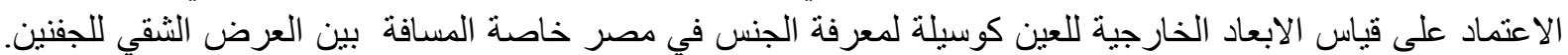

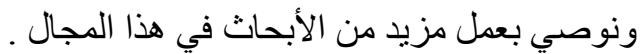

